\title{
Kerangka konsep penglibatan Politeknik dan industri dalam Mengaplikasikan Pembelajaran Berasaskan Kerja (PBK)
}

\author{
Syamhanim Ismail, Mimi Mohaffyza Mohamad*
}

Fakulti Pendidikan Teknikal dan Vokasional, Universiti Tun Hussein Onn Malaysia, 86400 Parit Raja, Malaysia

*Corresponding author: mimi@uthm.edu.my

\begin{abstract}
This concept paper discusses about the conceptual framework of qualitative case study research to show the input-process-output in more detail in achieving the goal of developing a suitable framework Work-based Learning (WBL) applied at the Polytechnic and industry through of the data to be acquired in the exploration of their experience in Work-based Learning involvement in the Polytechnic and industry. The concept paper will describe in detail the processes involved in research through the input process Work-based Learning models and theories. The process also needs to go through several phases such as interview technique to answer the all the research question and also several factors that will be found throughout the study. Finally, the output of the study will be designed as a result of research findings and appropriate Work-based Learning framework will be developed. Basically framework of this study is to identify and address as well as outline the problems faced by the Polytechnic and the industry in terms of bilateral relations in strengthening relationships to train students and institutions involved in WBL.
\end{abstract}

Keywords: Work-based learning; polytechnic; industry; collaboration

\begin{abstract}
Abstrak
Kertas konsep ini membincangkan tentang kerangka konsep kajian kualitatif berbentuk kajian kes dengan menunjukkan input-proses-output kajian dengan lebih terperinci dalam mencapai matlamat untuk membangunkan kerangka Pembelajaran berasaskan kerja (PBK) yang sesuai diaplikasikan di Politeknik dan industri melalui data yang akan diperolehi hasil penerokaan daripada mereka yang berpengalaman dalam penglibatan PBK di Politeknik dan industri. Kertas konsep ini akan menerangkan secara terperinci segala proses yang terlibat dalam proses input kajian menerusi model-model PBK dan teori PBK. Proses kajian pula perlu melalui beberapa fasa seperti kaedah temubual untuk menjawab segala persoalan kajian dan juga beberapa faktor yang akan ditemui sepanjang kajian ini dijalankan. Akhir sekali, output kajian akan direka bentuk hasil daripada penemuan kajian dan kerangka PBK yang sesuai akan dibangunkan. Pada asasnya kerangka hasil kajian ini dibangunkan adalah untuk mengetahui dan mengatasi serta menggariskan masalah yang dihadapi oleh Politeknik dan pihak industri dari sudut hubungan dua-hala dalam menjalinkan hubungan kerjasama untuk penglibatan pelajar dan institusi dalam PBK.
\end{abstract}

Kata kunci: Pembelajaran berasaskan kerja; politeknik; industri; kerjasama

(C) 2017 Penerbit UTM Press. All rights reserved

\subsection{PENGENALAN}

Pembelajaran Berasaskan Kerja (PBK) merupakan salah satu pembelajaran yang baru diperkenalkan di Malaysia. PBK menghubungkan segala bidang pekerjaan, pembelajaran kerja, pembelajaran di tempat kerja dan pembelajaran melalui kerja (Seagraves et al., 1996). Bahkan juga PBK merupakan salah satu pendekatan pembelajaran yang telah diamalkan di seluruh dunia selama bertahun-tahun dahulu yang mana menjuruskan kepada teori konstruktivisme iaitu suatu pembelajaran yang aktif dan dinamik serta berkembang sedikit demi sedikit sepanjang hayat seseorang individu (Wilson, 1997). Walaubagaimanapun PBK hanya sesuai digunakan dalam pengajian pendidikan tertiari dan diaplikasikan dalam pendidikan teknikal dan vokasional tetapi ia tidak sesuai untuk program yang lebih kepada disiplin akademik seperti sains ekonomi atau perniagaan (Stone, 1994). Sehubungan dengan itu, Lemanski et al. (2011) pula menyatakan bahawa PBK adalah istilah yang digunakan untuk menghuraikan program institusi pengajian dengan mempertemukan universiti-universiti dengan organisasi-organisasi kerja untuk mewujudkan peluang pengajian baru di tempat kerja. Merujuk pada Becker (2007), PBK merupakan pendekatan pembelajaran yang merangkumi pengalaman bekerja di mana pelajar perlu melalui proses pembelajaran di institusi dan menimba pengalaman serta aplikasi kemahiran dalam industri yang berkaitan dengan apa-apa yang diperlukan dialam kerja sebenar.

PBK merupakan salah satu kaedah penyampaian pengajaran dan pembelajaran yang inovatif. Pendekatan ini melibatkan kerjasama antara sektor pendidikan dan industri yang berkaitan. Kerjasama ini mengambil kira aspek penting yang terlibat dalam sesuatu sistem pendidikan iaitu pembangunan kurikulum, penyampaian pengajaran dan pembelajaran dan pentaksiran serta peperiksaan. Pendekatan ini adalah selaras dengan amalan diperingkat antarabangsa sepertimana yang dinyatakan melalui Oregon Work Based Learning Manual : An Educator's Guide (1998) "process which allows students to meet academic standards in a hands-on, real life environment while also developing employability skills and career awareness". Begitu juga mengikut Tajul Ariffin \& Ani Asmah (2009), PBK merupakan suatu kaedah pendekatan pembelajaran yang memberi pengalaman besar kepada pelajar dan membuka peluang yang lebih luas untuk 
menempatkan diri dalam bidang industri yang mereka ceburi. Kaedah PBK membolehkan jurang pendidikan dan dunia kerja yang semakin meluas dapat diminimumkan dengan adanya aplikasi konsep yang telah dipelajari dalam bilik darjah dan dunia sebenar. PBK juga merupakan program pengajaran yang menggunakan tempat kerja sebagai tapak untuk pembelajaran. Program pembelajaran ini juga berasaskan kerja yang mempunyai rancangan pengajaran dan pembelajaran formal secara langsung yang berkaitan dengan kerja pelajar berasaskan aktiviti pembelajaran yang berasaskan aktiviti pembelajaran kearah matlamat kerjaya. Kaedah PBK juga merupakan proses pembelajaran yang merangkumi pengalaman bekerja dan para pelajar perlu melalui proses pembelajaran di institusi dan menimba pengalaman serta aplikasi kemahiran di industri yang berkaitan dengan apa yang diperlukan di alam kerja sebenar (Wisconsin Work-based Learning Guide, 2002).

\subsection{PEMBELAJARAN BERASASKAN KERJA (PBK)}

Career Technical Education (2003) mendefinisikan PBK sebagai hasil pembelajaran daripada pengalaman kerja yang telah dirancang untuk menyumbangkan kepada perkembangan intelektual dan pembangunan kerjaya. Pengalaman kerja tersebut ditambah dengan pelbagai aktiviti yang berkaitan, proses pengukuhan atau perkembangan pembelajaran sepanjang proses pembelajaran. Hal ini akan menyumbangkan kepada perkembangan sikap, pengetahuan, kemahiran dan tabiat yang tidak mungkin akan berkembang melalui pengalam kerja secara sendirian. Iowa Education Department (2002) pula mendefinisikan PBK sebagai suatu perancangan dan perhubungan antara pengalaman di bilik darjah dengan realiti di alam pekerjaan dimana pengalaman menggunakan pendekatan PBK ini akan menyediakan pelajar dengan peluang pembangunan pengetahuan, kemahiran, sikap kebolehkerjaan yang akan mendorong kepada pemilihan kerjaya yang lebih jelas.

Arizona Work Based Learning Guide (1996) pula menyatakan bahawa PBK merupakan suatu peralihan pendidikan daripada institusi kepada kerjaya. Ia menggabungkan pembelajaran di institusi dengan pembelajaran di industri dan mewujudkan suatu pengalaman yang bersepadu kepada pelajar. Manakala United States 10 3rd (1994) melihat PBK sebagai suatu kaedah yang menggabungkan program latihan kerja dengan pengalaman kerja yang terancang termasuk latihan yang berkaitan dengan pra-pekerjaan dan kemahiran bekerja serta menguasainya secara komprehensif seterusnya diselaraskan dengan pembelajaran yang releven dengan kerjaya yang luas dan penganugerahan sijil kemahiran. Kemahiran tersebut meliputi kecekapan ditempat kerja, pengajaran dan pembelajaran yang berhubung dengan aktiviti yang memperkembangkan sikap positif bekerja, kebolehkerjaan, pengajaran luas dan semua aspek dalam industri.

Menurut Collin (2004) pula, objektif PBK adalah untuk membina ikatan sinergi antara pengetahuan, amalan kerja dan pembelajaran serta aplikasi maklumat dalam situasi praktikal kerja. PBK adalah pembelajaran yang aktif dengan perlaksanaan tugasan di tempat kerja termasuklah dapat meningkatkan kemahiran dan pemerolehan pengetahuan berkenaan dengan cara kerja dan amali. PBK juga memberi peluang kepada industri untuk mengukuhkan kemahiran yang berkaitan dengan akademik dan pihak institusi pula memainkan peranan untuk menekankan aplikasi kerjaya melalui pengajaran di dalam kelas. Pelajar-pelajar yang mengikuti program yang menggunakan kaedah PBK menunjukkan peningkatan yang positif dalam menyiapkan tugasan, penambahan kadar kehadiran, dan pemerolehan pengijazahan yang lebih tinggi. Pengalaman secara langsung di tempat kerja yang melibatkan pelajar lebih berkesan daripada berorientasikan buku dan pembelajaran melalui guru (Bailey, Hughes \& Moore, 2004).

PBK berkonsepkan kepada suatu kaedah yang digunakan untuk memperluaskan sempadan pembelajaran antara bilik darjah dengan situasi kerja yang sebenar dengan melibatkan komuniti sebagai sumber sesuatu pembelajaran (National Centre on Secondary Education and Training (NCSET), 2011). PBK memberi peluang kepada pelajar untuk mempelajari pelbagai jenis kemahiran yang dapat mewujudkan hubungan sinergi antara pembelajaran di institusi dengan dunia pekerjaan. Ia digunakan sebagai salah satu cara untuk merapatkan jurang yang sedia ada antara teori dan latihan sebenar dan cuba menjadikan sesuatu pembelajaran itu lebih bermakna. Okon (2011) pula menyatakan bahawa PBK merupakan sebagai suatu pembelajaran yang memberikan pengalaman dengan menggunakan persekitaran kerja sebagai satu komponen penting dalam kurikulum. Melalui PBK, pelajar akan mendapat pengalaman pembelajaran melalui kerjasama majikan industri dengan institusi pendidikan. Kerjasama ini akan memberi peluang kepada pelajar untuk memperoleh pelbagai jenis kemahiran kerana ianya mendedahkan pelajar kepada akademik dengan pembangunan kerjaya sebenar secara serentak. PBK terus melangkah maju dengan menghubungkan pembelajaran di institusi, dunia kerja dan mewujudkan peluang pekerjaan dengan melibatkan seseorang pelajar itu dalam persekitaran pekerjaan yang profesional dan pembelajaran yang sesuai yang dapat memberikan impak yang postitif kepada pelajar dalam dunia pekerjaan (Jarrad \& Jefsioutine, 2006).

\subsection{MODEL PBK}

Terdapat lima langkah penting telah dikenal pasti dalam menentukan keberkesanan pelaksanaan PBK. Lewis (1997) menyatakan bahawa satu strategi menyeluruh perlu dirangka dan dihubungkan dengan setiap tahap dalam PBK. Kemudian ia haruslah melibatkan perhubungan dua hala antara majikan di pihak industri dengan institusi pendidikan. Untuk memastikan keberkesanan PBK ini, semua pihak termasuk pihak sekolah, badan perniagaan, intitusi pendidikan, rakan komuniti dan ibu bapa perlu sama-sama memberi komitmen terhadap perlaksanaan kaedah ini. Semua program yang telah dirancang haruslah menyediakan pelajar asas yang kuat terhadap maklumat kerjaya dalam satu rancangan kursus yang teratur melalui sekolah dan akhir sekali, program PBK yang berkesan akan tercapai dengan adanya integrasi akademik dan pembelajaran vokasional. Beberapa model PBK yang digunakan adalah seperti berikut:

\section{Model Arizona Work-Based Learning Resource Guide}

Menurut Lynne (1996) terdapat model yang telah digunakan untuk perlaksanaan PBK daripada Arizona Work-Based Learning Resource Guide. Rajah 1 menunjukkan model perlaksanaan PBK di Arizona. Dalam model tersebut didapati bahawa PBK memerlukan kerjasama ataupun hubungan dua hala daripada institusi pendidikan dan juga pihak industri yang dihubungkan dengan pelbagai aktiviti dan sumber. Walaubagaimanapun aktiviti dan sumber yang telah berlaku dalam model ini tidak dijelaskan secara spesifik. Hal ini disokong oleh Otala (1994) yang menyatakan bahawa hubungan dua hala antara institusi pendidikan dan pihak industri dapat menjadikan kaedah PBK ini lebih efisien. 
Institusi pendidikan

(Sumber dan aktiviti)

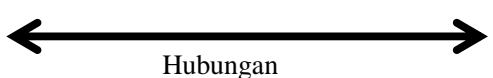

(Sumber dan aktiviti)
Pihak industri

(Sumber dan aktiviti)

Rajah 1 Model PBK Arizona Work-Based Learning Resource Guide

\section{Model Hubungan Antara Institusi Teknikal Dan Industri}

Model hubungan antara institusi teknikal dan industri oleh Council of Ontario Universiti: Sectoral Skills Needs (1998) pula menggambarkan hubungan antara industri dengan sistem institusi pendidikan teknikal dan vokasional. Institusi adalah sumber utama pekerja baru dalam pelbagai bidang pekerjaan, dan majikan boleh menilai aktiviti dan pendidikan melalui produk yang dikeluarkan oleh mereka, iaitu graduan. Model dalam Rajah 2 melihat hubungan antara sistem institusi dan industri dalam melahirkan lulusan dan pekerja yang memiliki pengetahuan dan kemahiran yang mencukupi yang diperlukan oleh industri kini. Industri akan mendapat manfaat sekiranya pendidikan yang dilaksanakan oleh institusi mengikut perkembangan teknologi.

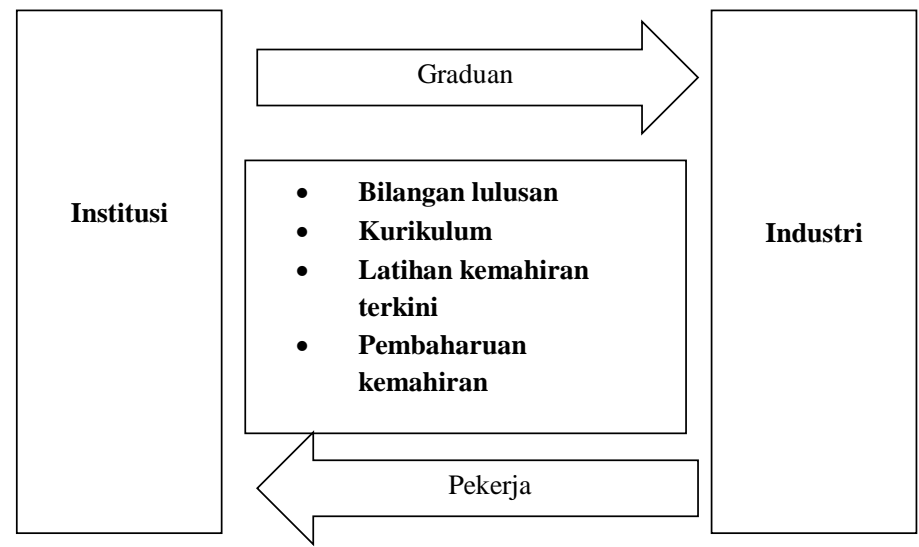

Rajah 2 Model hubungan antara institusi teknikal dan industri

\section{Model Edmund's}

PBK umumnya dianggap sebagai hubungan tiga hala antara pelajar, majikan dan universiti. Model Edmunds' telah menghubungkan pelajar, majikan dan institusi pendidikan, yang menghubungkan latihan (pelajar dan majikan), pendidikan (pelajar dan institusi pendidikan) dan kodifikasi pengetahuan (majikan dan institusi pendidikan) untuk PBK. Rajah 3 menunjukkan Model Edmunds' yang digunakan dalam kaedah PBK.

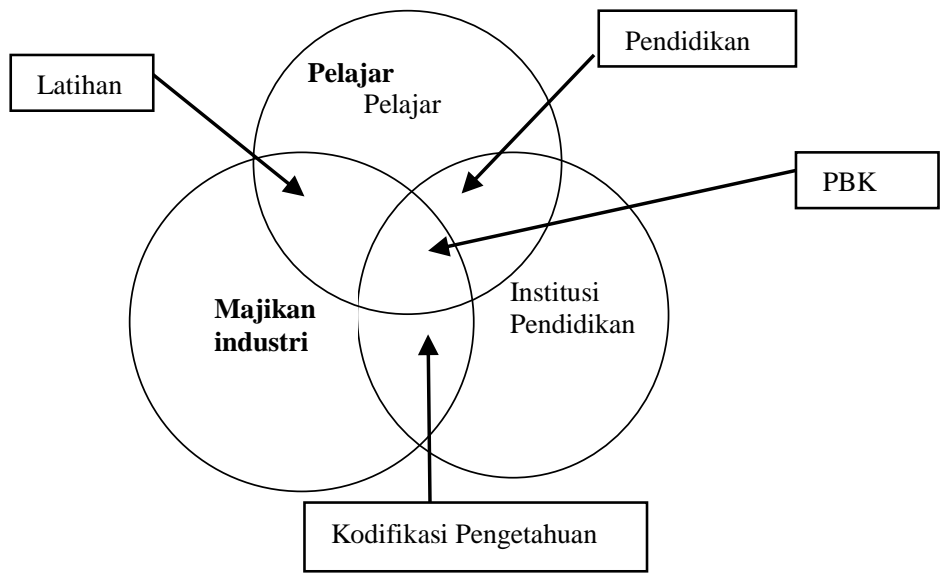

Rajah 3 Model Edmunds'

Edmunds menyatakan bahawa Model Edmunds' menentukan Pembelajaran Berasaskan Kerja (PBK) sebagai keadaan di mana pengalaman pembelajaran adalah termasuk pelajar, majikan dan institusi pendidikan. Edmunds mempertikaikan situasi yang hanya dua pihak sahaja yang bekerjasama. Edmunds mencadangkan supaya majikan di industri atau institusi pendidikan menjana pengetahuan dengan menggabungkan pembelajaran di tradisional dengan latihan ditempat kerja yang sebenar. Edmunds juga mengatakan bahawa PBK adalah tidak menyamai akademik biasa. Ia adalah secara langsung berkaitan dengan kerja individu, konteks kerja yang spesifik dan dibezakan daripada pendidikan umum (Edmunds, 2007) 


\section{Rumusan Model PBK}

Berdasarkan kepada semua model yang berkaitan dengan PBK yang telah dibincangkan disini, didapati bahawa setiap model PBK menekan perhubungan dua hala antara institusi pendidikan dan juga industri. Namun semua model terbabit tidak dibincangkan cara ataupun aktiviti yang perlu dilakukan oleh kedua- dua belah pihak untuk memastikan hubungan kerjasama terus berjalan dengan lancar. Oleh yang demikian, penyelidik telah melihat hal ini sebagai suatu kekurangan yang perlu diberi kajian lanjutan untuk memastikan program yang menggunakan PBK terus berkembang dan berjalan seperti yang dirancang.

\subsection{KONSEP PERLAKSANAAN PBK}

PBK merupakan suatu kaedah yang digunakan untuk memperluaskan sempadan pembelajaran antara bilik darjah dengan situasi kerja yang sebenar dengan melibatkan komuniti sebagai sumber sesuatu pembelajaran pembelajaran (National Centre on Secondary Education and Training (NCSET), 2011). Konsep perlaksanaan PBK adalah untuk memberi peluang kepada pelajar untuk mempelajari pelbagai jenis kemahiran yang dapat mewujudkan hubungan sinergi antara pembelajaran di institusi dengan dunia pekerjaan. Ia digunakan sebagai salah satu cara untuk merapatkan jurang yang sedia ada antara teori dan latihan sebenar dan cuba menjadikan sesuatu pembelajaran itu lebih bermakna. Rajah 4 menunjukkan kerangka konsep tentang faktor yang mempengaruhi penglibatan industri dengan politeknik dalam aspek motivasi, potensi faedah yang akan diperolehi dan halangan yang akan ditempuhi oleh politeknik dan industri bagi menjayakan program yang menggunakan kaedah PBK.

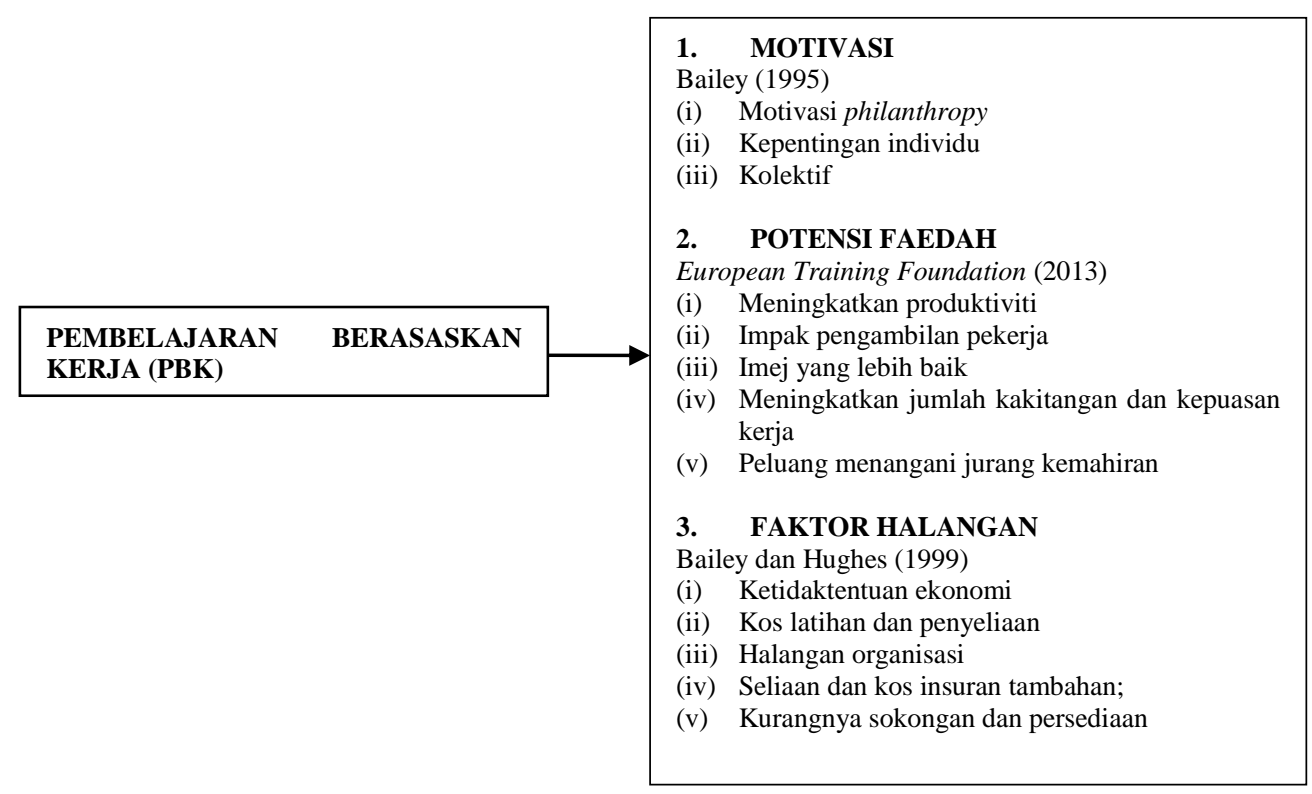

Rajah 4 Kerangka Konsep

\section{Faktor Yang Mempengaruhi Penglibatan Dalam PBK (Motivasi)}

Penglibatan antara institusi pendidikan dan industri amat penting dalam menjayakan pembelajaran yang menggunakan kaedah PBK. Crutis (1986) mendapati bahawa kerjasama antara industri dengan institusi pendidikan dalam merancang program pendidikan berada di tahap yang minima. Pihak industri sebagai pengguna tenaga kerja perlu bekerjasama bagi mengenal pasti latihan-latihan kemahiran yang diperlukan. Dengan adanya perhubungan ini program-program pendidikan vokasional menjadi lebih berkaitan terhadap kehendak industri.Hal ini disokong oleh Akta School to Work Opportunities (1994) yang mendapati bahawa tiga majikan industri daripada dua belas program yang dijalankan mempunyai masalah untuk melatih pelajar berbanding pekerja dan lima daripadanya mengalami masalah berkaitan menyediakan tempat untuk pelajar PBK (Bailey \& Hughes, 1999). Oleh yang demikian, untuk memastikan program yang menggunakan kaedah PBK ini mendapat penglibatan yang total daripada industri, Bailey (1995) telah mengenal pasti tiga komponen yang mempengaruhi keputusan majikan industri untuk mengambil bahagian dalam kaedah PBK iaitu motivasi philantrophy, kepentingan individu dan kolektif.

\section{Motivasi Philanthropy}

Komponen pertama yang mempengaruhi keputusan majikan untuk mengambil bahagian dalam PBK adalah motivasi philanthropy (Bailey, 1995). Menurut Lynn \& Wills (1994), isu yang mempengaruhi penglibatan majikan di industri dalam kaedah PBK adalah keupayaan majikan untuk mendapatkan pelaburan dalam program latihan asas seperti PBK. Seperti yang boleh kita lihat dalam satu kajian yang melibatkan lima belas orang pelajar yang mengikuti program menggunakan kaedah PBK di industri mendapati bahawa majikan yang melibatkan diri dalam PBK adalah untuk meningkatkan servis dikalangan komuniti serta mengambil peluang ini kerana dapat memberi 
manfaat kepada firma mereka sendiri seperti dapat mewujudkan perhubungan sosial yang positif dan memberi sumbangan kepada institusi pendidikan (Bailey, Hughes, dan Barr 1998). Walaubagaimanapun, dalam tujuh kajian yang dijalankan oleh Bassi and Ludwig (2000) pula telah mendapati bahawa walaupun program PBK ini dapat memberi faedah kepada industri tetapi ini tidak menjamin majikan industri untuk terlibat dengan lebih lama. Hal ini didorong oleh kebimbangan semasa dan juga penstafan.

Hasil kajian oleh penyelidik Universiti Colombia pula terhadap 300 majikan industri yang terlibat dalam program PBK di lima buah sekolah mendapati bahawa motivasi philanthropy merupakan alasan yang kukuh untuk majikan industri melibatkan diri dalam program menggunakan kaaedah PBK. Dua motivasi philantrophy yang paling mempengaruhi keputusan majikan industri untuk terlibat adalah untuk menambahbaik sistem pendidikan awam dan melibatkan diri dalam servis komuniti. Walaubagaimanapun, kajian ini juga melaporkan bahawa banyak industri mengatakan bahawa berorentasikan perniagaan adalah sebab kenapa mereka terlibat dalam program menggunakan kaedah PBK. Dalam erti kata yang lain, program yang menggunakan kaedah PBK dapat memberi pelajar pengamalan serta dapat memberi akses kepada majikan-pekerja yang akan menyumbangkan output kepada industri (Bailey, Hughes, Barr, 2000).

\section{Kepentingan Individu}

Penglibatan majikan industri dalam program PBK yang disebabkan oleh kepentingan individu bermula apabila majikan tersebut mendapat kelebihan dari aspek perhubungan awam dan sumber buruh yang rendah. Faedah yang diperolehi oleh industri daripada perhubungan awam dapat dicapai dengan penyusunan pelajar secara sistematik semasa proses pembelajaran di industri. Imbuhan istimewa kepada pelajar yang terlibat dalam PBK juga adalah merupakan insentif penting kepada industri kecil untuk mengisi kekosongan pekerja sementara dengan pelajar tersebut berbanding memberi jawatan tersebut kepada pekerja yang perlu diupah dengan gaji yang tinggi. (Mathias, 2001).

Sebilangan besar majikan di industri US mellihat program seperti kaedah PBK ini merupakan suatu cara yang bijak untuk mendapat kepentingan dari pelbagai pihak terutamanya buruh sementara yang bergaji minima (Lynn \& Wills, 1994). Manakala kakitangan sekolah Philadelphia pula mengatakan bahawa hospital Philadelphia yang terlibat dengan program PBK menggunakan alasan untuk terlibat adalah untuk perhubungan awam. Tambahan pula, penglibatan sesebuah industri boleh membantu dan menarik minat industri lain untuk pengambilan selanjutnya menjayakan program PBK serta sekaligus dapat membuka mata industri lain untuk terlibat (Hughes, 1998). Dalam satu kajian yang dijalankan oleh Office of Technology Assessment menyatakan bahawa hampir dua pertiga daripada majikan menyebut matlamat pengambilan pelajar sebagai alasan paling penting untuk penyertaan mereka (Office of Technology Assessment, 1995). Apabila sesebuah industri terlibat dalam program PBK, mereka dapat membuat satu pelaburan dalam perusahaan mereka dan pada masa yang sama dapat mengurangkan perbelanjaan pengambilan pekerja kerana pelajar PBK adalah percuma atau dibayar satu upah yang rendah.

Di Kolej Komuniti LaGuardia, mereka menekankan kepada majikan industri bahawa dengan terlibat dalam program PBK, industri dapat mengurangkan kos syarikat dan mendapat pekerja sementara yang lebih berpengalaman. Kazis \& Goldberger (1995) pula menyatakan bahawa majikan melaporkan dengan mempunyai pelajar PBK di tempat kerja, ia dapat memotivasikan pekerja-pekerja sedia ada dan meningkatkan kualiti penyeliaan dan melatih, untuk tenaga kerja dewasa.Beberapa buah negara juga telah cuba untuk meningkatkan motivasi individu majikan melalui penggunaan insentif kewangan untuk penyertaan program PBK. Dari laluan STWOA pada tahun 1994 hingga 1996, kerajaan Persekutuan memberi \$643,000,000 kepada dua puluh sembilan negeri, beberapa di antaranya termasuklah Michigan, Oregon, dan Wisconsin untuk digunakan sebahagian daripada dollar tersebut dan menawarkan insentif dalam bentuk kredit cukai atau subsidi gaji untuk industri yang terlibat dengan program berbentuk PBK (Hershey et al., 1997).

\section{Kolektif}

Kolektif merupakan salah satu komponen yang mempengaruhi keputusan majikan industri untuk mengambil bahagian dalam kaedah PBK. Kolektif dapat dicapai melalui perbincangan antara dua belah pihak dengan membincangkan terma dan dan objektif khusus yang ingin dicapai. Dalam program PBK, perbincangan tersebut adalah di antara majikan industri dengan institusi pendidikan seperti Politeknik KPM. Proses tawar-menawar berhubung upah, masa bekerja, pampasan dan cuti akan dibincangkan semasa perbincangan dan sebarang persetujuan akan dimeterai. Perbincangan tersebut juga akan melibatkan proses memberi dan menerima di antara majikan industri dengan pihak institusi pendidikan dalam satu kontrak perjanjian (Mill, 1994). Begitu juga dengan Wrigh (2005), yang menyatakan bahawa kolektif dapat dicapai sekiranya suatu perbincangan antara majikan dan istitusi pendidikan dipersetujui terma dan syarat oleh kedua-dua belah pihak.Sementara itu Fossum (1995) pula menjelaskan tentang perbincangan yang menjurus kepada kolektif adalah berdasarkan kepada perspektif ekonomi dan perspektif tingkah laku psikologi. Dari perspektif ekonomi, perbincangan tersebut dinyatakan sebagai perbincangan sukarela di antara dua pihak dan akan mencapai kata sepakat untuk mewujudkan perjanjian yang akan memberi faedah kepada kedua-duanya yang mana majikan dapat meneruskan operasi syarikat dan institusi mendapat kebenaran untuk meletakkan pelajar dalam mengikuti program PBK. Mengikut perspektif tingkah laku (psikologi) pula, perbicangan yang akan menjurus kepada kolektif adalah perbincangan antara kedua belah pihak yang mempunyai konflik kepentingan berbeza yang memerlukan penyesuaian dan kerjasama kedua belah pihak. Dalam proses perbincangan tersebut, sifat dan perasaan berperanan penting memandangkan ia mempengaruhi rasional dalam membuat keputusan (Fossum, 1995).

Maimunah (1998) menyatakan bahawa perbincangan untuk mencapai kolektif atau perbincangan bersama ialah proses di mana para majikan industri dan wakil istitusi pendidikan bagi program PBK berunding secara mendalam mengenai PBK. Manakala Poon (2002) telah memperincikan bahawa tawar menawar semasa perbincangan untuk mencapai kolektif merupakan suatu proses yang membolehkan wakilwakil pihak majikan dan wakil pihak institusi pendidikan bertemu dengan niat jujur untuk merundingkan suatu perjanjian buruh di mana ia mengandungi peruntukan-peruntukan tentang upah, masa bekerja, keadaan kerja dan lain-lain lagi. Perspektif kolektif adalah dimana industri tidak mungkin mendapat manfaat serta-merta atau terus daripada pelatih itu sendiri. Pelaksanaan yang meluas bagi peralihan sekolah ke kerja akan mengukuhkan penawaran buruh untuk semua. PBK juga akan membantu untuk membangunkan tenaga kerja yang lebih mahir secara keseluruhan, yang mana menjadi insentif bagi industri untuk mengambil bahagian. Terdapat beberapa contoh kolektif dapat dilihat daripada majikan di industri apabila mereka mengharap untuk mendapatkan secara tersendiri daripada usaha mereka. Manfaat yang spesifik bergantung kepada minat majikan industri terhadap keadaan yang tertentu dan jenis industri mereka, tetapi termasuk 
perhubungan awam yang positif, buruh percuma atau buruh kos rendah serta pengambilan buruh untuk jangka masa panjang (Hughes, 1998).

Mattias (2001) menyatakan bahawa keengganan majikan untuk melabur dalam latihan juga boleh dikatakan tindakan kolektif. Walaubagaimanapun, terdapat satu kerangka institusi yang sesuai menyatakan bahawa kolektif boleh dinyatakan dan dikawal selia. Jika tidak, industri lain boleh mendapat manfaat walaupun mereka tidak terlibat dalam program yang menggunakan kaedah PBK. Oleh yang demikian, setiap tindakan kolektif digunakan untuk mengatasi adanya 'sleeping partner'. Contohnya di Jerman, sistem pendidikan mereka memaksa industri untuk mengambil bahagian dalam program berbentuk seperti PBK. Ringkasannya, penglibatan majikan industri dalam skala yang besar tidak dapat dicapai secara kolektif dalam program PBK sekiranya wujud masalah kos latihan terutamanya kos penyeliaan, tingkah laku 'sleeping partner' dan kekangan kerangka institusi pendidikan untuk mengawal selia kepentingan kolektif. Tambahan pula, majikan boleh memilih alternatif yang lain untuk dengan menggaji pekerja dewasa dan memberi latihan kepada pekerja mereka tanpa menggunakan pelajar PBK sebagai sumber buruh.

\section{Potensi Faedah Yang Diperolehi Daripada Keterlibatan Industri Dalam Kaedah PBK}

Menurut European Training Foundation (2013) melalui hasil kajiannya di luar negara mendapati terdapat beberapa potensi faedah yang akan diperolehi daripada keterlibatan industri dalam kaedah PBK iaitu meningkatkan produktiviti, impak pengambilan pekerja, imej yang lebih baik, meningkatkan jumlah kakitangan dan kepuasan kerja, peluang menangani jurang kemahiran dan meningkatkan produktiviti.

\section{Meningkatkan Produktiviti}

Terdapat beberapa faktor yang mempengaruhi produktiviti iaitu jenis pelaburan, modal, penyelidikan dan pembangunan negara, penggunaan tenaga, peraturan yang dikenakan oleh kerajaan, loji dan peralatan, kos tenaga, gabungan tenaga kerja serta etika kerja (Murthy, 2006). Dalam konteks PBK, produktiviti dirujuk kepada hasil yang dikeluarkan oleh pihak industri daripada inputnya iaitu pelajar dari program PBK yang menjalani latihan di tempat mereka. Titik permulaan penting dalam PBK adalah sumbangannya dalam menghasilkan produktiviti dan inovasi kepada industri. Organisasi kerja, struktur, hubungan pekerja dan gaji dapat meningkatkan produktiviti dan inovasi sesebuah industri. Terdapat banyak kajian di Jepun yang mengaitkan produktiviti sesuatu industri berkaitan dengan pendidikan vokasional secara formal dan latihan. Sako \& Dore (1998) menyatakan bahawa program yang menggunakan jenis 'on job training', PBK, kumpulan kecil dan pembelajaran di rumah adalah penting kepada produktiviti industri di jepun dan dilihat sebagai satu-satunya cara untuk memupuk dan mengekalkan pekerja yang berkemahiran. Manakala Itoh (1994) menyatakan bahawa insentif dan kaedah kerja organisasi dalam industri Jepun menggalakkan pembentukan modal insan industri tersebut untuk menggalakkan pemerolehan dan pengekalan dalam industri. Pelbagai kajian menunjukkan bahawa pembelajaran boleh dilaksanakan di industri melalui kepelbagaian tugas, penyeliaan, mentoring serta PBK (Koike, 2002). Hal ini disokong oleh penyelidikan yang menunjukkan persekitaran kerja pembelajaran boleh menyumbang kepada inovasi dalam perusahaan (Deitmer, 2011; Toner, 2011). Pendekatan Jepun kepada hubungan di antara PBK dan produktiviti perusahaan mempunyai perkaitan dengan pendidikan vokasional dan latihan formal.

Menurut National Apprenticeship Service 81\% daripada majikan mengatakan perniagaan mereka lebih produktif dengan adanya pelajar PBK. Mereka berjaya meningkatkan produktiviti perniagaan dengan $£ 214$ seminggu. $80 \%$ daripada majikan merasakan bahawa perantisan berjaya mengurangkan proses pengambilan kakitangan. Memetik pernyataan daripada Bentleys Motor dalam National Apprenticeship Service, pelajar PBK yang telah dilatih boleh menjadi pekerja yang berkemahiran tinggi, efektif dan bernilai. Ini adalah kerana pelajar PBK yang telah dilatih mempunyai pandangan dan dapat menjana idea baru kepada syarikat serta menjadi sumber inspirasi. Gravan et al. (2003) turut mencadangkan bahawa pelan pembangunan PBK yang disediakan memberi kebaikan kepada organisasi dan individu dalam organisasi termasuklah meningkatkan produktiviti dengan meningkatkan keprihatinan dalam pembangunan pekerja untuk meneraju kepada prestasi yang lebih baik kepada industri

\section{Impak Pengambilan Pekerja}

Dalam program PBK, pelajar perlu mengaplikasikan pengetahuan dalam situasi yang sebenar dan seharusnya perkara ini dapat membangunkan kemahiran bekerja dan menjadikan mereka lebih tertarik untuk diambil sebagai pekerja. Penglibatan pelajar dalam kaedah ini dapat menarik perhatian majikan industri untuk mengambil mereka sebagai pekerja kerana mereka telah terbiasa dengan budaya dan etika syarikat tersebut serta terlatih secara langsung atau bersedia untuk dilatih secara terus dengan operasi perniagaan mereka (Taylor, 2001). National Academy Foundation Guide to Work-Based Learning: A Continuum of Activities and Experience pula menyatakan bahawa melalui PBK, ia dapat meningkatkan sumbangan kepada pembangunan pekerja. Hal ini juga disokong oleh pernyataan daripada Alaska Work Based Learning Guide (2003) yang menyatakan bahawa PBK dapat memberi ruang latihan dan mempengaruhi pengambilan pekerja dalam sesebuah syarikat untuk memenuhi keperluan tenaga kerja mereka. Disamping itu juga, ia membolehkan majikan mengenal pasti pelajar PBK yang berpotensi untuk di ambil sebagai pekerja.

PBK juga dapat memberikan potensi faedah dengan memotivasikan pekerja yang sedia ada dan juga dapat kos pengambilan pekerja yang efektif. Disamping itu juga proses pemilihan dan pengambilan pekerja dapat dilakukan oleh majikan berdasarkan kepada kerja dan latihan yang sesuai serta memberi impak kepada pengambilan pekerja yang terbaik (A Guide for Employers for Work-Based Training, 2011)

\section{Imej Yang Lebih Baik}

Dalam program PBK, pelajar perlu mengaplikasikan pengetahuan dalam situasi yang sebenar dan seharusnya perkara ini dapat membangunkan kemahiran bekerja dan menjadikan mereka lebih tertarik untuk diambil sebagai pekerja. Penglibatan pelajar dalam kaedah ini dapat menarik perhatian majikan industri untuk mengambil mereka sebagai pekerja kerana mereka telah terbiasa dengan budaya dan etika syarikat tersebut serta terlatih secara langsung atau bersedia untuk dilatih secara terus dengan operasi perniagaan mereka (Taylor, 2001). National Academy Foundation Guide to Work-Based Learning: A Continuum of Activities and Experience pula menyatakan bahawa 
melalui PBK, ia dapat meningkatkan sumbangan kepada pembangunan pekerja. Hal ini juga disokong oleh pernyataan daripada Alaska Work Based Learning Guide (2003) yang menyatakan bahawa PBK dapat memberi ruang latihan dan mempengaruhi pengambilan pekerja dalam sesebuah syarikat untuk memenuhi keperluan tenaga kerja mereka. Disamping itu juga, ia membolehkan majikan mengenal pasti pelajar PBK yang berpotensi untuk di ambil sebagai pekerja.

PBK juga dapat memberikan potensi faedah dengan memotivasikan pekerja yang sedia ada dan juga dapat kos pengambilan pekerja yang efektif. Disamping itu juga proses pemilihan dan pengambilan pekerja dapat dilakukan oleh majikan berdasarkan kepada kerja dan latihan yang sesuai serta memberi impak kepada pengambilan pekerja yang terbaik (A Guide for Employers for Work-Based Training, 2011)

\section{Meningkatkan Jumlah Kakitangan Dan Kepuasan Kerja}

Menurut hasil kajian Boudreau \& Tichy (2005) menunjukkan bahawa atitud kerja dan kepuasan kerja adalah faktor yang terpenting dalam pengekalan kerja. Program PBK yang telah digunakan oleh Metropolitan College of Louisville, Kentucky telah menunjukkan bahawa melalui PBK dapat memberikan kelebihan kepada kesemua pihak dengan meningkatkan jumlah enrolmen, mendidik tenaga kerja, meningkatkan pengekalan pekerja, dan memastikan yang kakitangan mencukupi bagi sesebuah industri (Riggert et al., 2004). Hasluck et al. (2008) juga menyatakan bahawa program PBK boleh membawa pertambahan pengekalan kakitangan dalam industri. Hal ini dapat dibuktikan apabila sebanyak 36\% daripada pelajar PBK di Switzerland kekal bekerja dengan industri tersebut selepas tamat pengajian (Dionisius et al., 2008).

Hasil kerjasama antara syarikat gergasi seperti Westfield, Debenhams dan Matalan dengan Kolej Derby telah menunjukkan bahawa pelajar PBK lebih berkualiti kerana lebih produktif dan dapat membantu pengekalan kakitangan syarikat. Syarikat tersebut dapat meningkatkan purata pencapaian syarikat sebanyak $98 \%$ dan pengekalan pelajar PBK sebanyak $81 \%$. Hal ini telah menunjukkan bahawa PBK dapat meningkatkan pengekalan dan kepuasan pekerja disamping mewujudkan pekerja yang lebih produktif (Pearson Education Ltd, 2014). Pelbagai kajian penyelidik oleh Smith (1996); Sims and Golden (1998); CBI (1998) \& Canning (1999) mendapati bahawa melalui PBK majikan di industri akan mendapat persepsi positif daripada pekerja dengan kesetiaan terhadap majikan serta pengekalan kerja. Hal ini juga disokong oleh kajian Glass et al. (2002) yang menyatakan bahawa PBK dapat menambahbaik moral pekerja mereka dan meningkatkan purata pengekalan pekerja yang merupakan motivasi utama sebanyak 14\% oleh majikan mereka.

\section{Peluang Menangani Jurang Kemahiran Dan Meningkatkan Produktiviti}

PBK merupakan pemangkin kepada penglibatan dan kejayaan pelajar. Ia juga dapat meningkatkan pembangunan tenaga kerja dan merapatkan jurang kemahiran. PBK menyediakan peluang kerjasama antara industri dengan institusi pendidikan untuk melahirkan pelajar yang memenuhi permintaan pasaran kerja dan mendapat pekerjaan yang lebih baik. Ia juga memberi peluang untuk mendedahkan pelajar kepada perhubungan profesional untuk menjana pengetahuan dan kemahiran yang baru serta etika kerja berdisiplin yang diperlukan untuk berjaya dalam pekerjaan. Hal ini berikutan lebih 300,000 pelajar sekolah tinggi California setiap tahun tamat pengajian tanpa pengalaman atau kemahiran dan merupakan suatu beban kepada negara California (America's Edge, 2013). Sekiranya kaedah PBK diperkenalkan dalam institusi pendidikan di California, adalah tidak mustahil ianya dapat membantu pelajar mereka dari sudut kebolehkerjaan.

Menurut hasil kajian 2012 Chronicle of Higher Education/Marketplace pula mendapati bahawa majikan lebih memilih graduan yang mengikuti program PBK daripada graduan kolej yang lain sebagai pekerja. Ini adalah kerana mereka yakin bahawa pelajar PBK mempunyai kemahiran yang diperlukan oleh industri pada masa kini (Shoenfelt, 2013). Vermont Agency of Education (2013) pula menyatakan bahawa PBK menghubungkan pelajar dengan aktiviti di tempat sebenar dengan majikan dan direka khas untuk menambahkan pengetahuan dan kemahiran pelajar. Pengalaman di tempat kerja yang disokong dengan arahan dan aktiviti, memperkukuhkan, memperbaiki atau melanjutkan pembelajaran yang berlaku semasa kerja supaya pelajar membangunkan sikap, pengetahuan, kemahiran, dan tabiat yang tidak boleh diperkembangkan daripada pengalaman kerja semata-mata. Kejayaan PBK adalah dapat dibuktikan apabila industri yang terlibat dapat menunjukkan bahawa dengan mengambil pelajar program PBK sebagai pekerja dapat merapatkan jurang kemahiran bagi syarikat mereka (The Ohio State University Extension, 2009).

\section{Faktor Utama Yang Menghalang Pihak Industri Untuk Terlibat Dengan Kaedah PBK}

Menurut Bailey \& Hughes (1999), terdapat beberapa faktor yang menghalang pihak industri untuk terlibat dengan kaedah PBK iaitu ketidaktentuan ekonomi, kos latihan, halangan organisasi, seliaan dan kos insuran tambahan, kurangnya sokongan dan persediaan.

\section{Ketidaktentuan Ekonomi}

Ketidaktentuan ekonomi merupakan salah satu faktor yang mendorong titik tolak keterlibatan industri dalam program PBK. 79\% pekerja yang telah mengikuti program PBK melaporkan bahawa majikan mereka menyatakan bahawa faktor ekonomi menyebabkan mereka terlibat dalam PBK kerana dapat meningkatkan kualiti perkhidmatan atau produk, menjadikan syarikat itu lebih berdaya saing, meningkatkan kecekapan dalam kerja, mengikuti perkembangan teknologi, meningkatkan fleksibiliti pekerja serta dapat meningkatkan produktiviti. Sekiranya ekonomi tidak menentu, hal yang sebaliknya akan berlaku dan ini akan menyebabkan majikan industri merasa terbeban dan menarik diri daripada menyertai program berbentuk PBK (Glass et al., 2002).

Menurut hasil kajian OTA dalam Herdman (1995) mendapati bahawa sebanyak 9\% menyatakan bahawa ketidaktentuan ekonomi merupakan faktor utama menghalang industri untuk terlibat dalam PBK manakala $20 \%$ lagi menyatakan ketidaktentuan ekonomi merupakan faktor sampingan yang menghalang industri untuk terlibat dalam PBK. Hal ini juga disokong oleh European Centre for the Development of Vocational Training (2011) yang menyatakan bahawa majikan industri akan mengurangkan pengambilan pelajar untuk menjalani latihan di syarikat mereka seperti pelajar program PBK untuk memastikan tekanan pasaran ekonomi tidak menjejaskan perniagaan mereka. Alaska Work Based Learning Guide (2003) turut menyokong hasil kajian dan pernyataan di atas yang menyatakan faktor ketidaktentuan ekonomi merupakan faktor utama yang menghalang majikan industri untuk terlibat dalam PBK 


\section{Kos Latihan}

Berdasarkan kepada hasil kajian Worrells (2010) mendapati bahawa majikan industri sukar untuk menetapkan kos latihan atau bayaran kepada pelajar yang menjalani PBK di syarikat terbabit iaitu sebanyak 35.7\%. European Training Foundation (2013) pula menyatakan bahawa program PBK memerlukan syarikat mengeluarkan kos termasuklah gaji atau elaun untuk dibayar kepada pelajar PBK, kos yang berkaitan dengan pengawasan dan bimbingan, alatan dan bahan, pertadbiran dan lain-lain perbelanjaan. Hal ini sangat membebankan industri dan menyebabkan mereka kurang berminat untuk terlibat dalam kaedah PBK.

Walaubagaimanapun, keadaan ini berbeza dengan kaji selidik majikan yang dijalankan oleh Kementerian Persekutuan Jerman Pendidikan dan Penyelidikan pada tahun 2003 yang mendapati bahawa kira-kira tiga suku daripada syarikat-syarikat melaporkan bahawa PBK memberikan mereka peluang untuk memilih dan pekerja yang terbaik Dalam kaji selidik yang sama, hampir $60 \%$ pula menyatakan bahawa ini PBK juga menyumbang kepada mengurangkan kos yang terlibat dalam pengambilan pekerja yang lebih berpengalaman (Axmann, 2004).

\section{Halangan Organisasi}

Pengurusan, faktor-faktor organisasi dan tempat kerja akan mempengaruhi kepada kesediaan syarikat untuk melabur dalam program latihan yang berbentuk PBK hal ini dibuktikan apabila beberapa penyelidik meyatakan bahawa halangan daripada pekerja dalam syarikat itu sendiri merupakan halangan organisasi untuk terlibat dalam kaedah PBK (Campbell, 2003; Kaca et al., 2002; Belanda et al., 2002; Schick, 2005). Sesetengah majikan yang ditemuramah oleh Schick (2005) juga melaporkan kekurangan minat dalam kalangan pekerja merupakan alasan untuk mereka tidak melabur dalam latihan seperti PBK.

Alaska Work Based Learning Guide (2003) dan Hughes (2002) menyatakan bahawa halangan organisasi daripada majikan industri itu sendiri merupakan faktor utaman yang menghalang penglibatan yang aktif dalam PBK. Menurut hasil kajian OTA dalam Herdman (1995) pula mendapati bahawa sebanyak $14 \%$ daripada majikan menyatakan bahawa halangan organisasi merupakan faktor utama yang menghalang mereka daripada terlibat daripada program PBK manakala 12\% majikan lagi berasakan halangan organisasi merupakan faktor sampingan yang menghalang mereka daripada terlibat dengan PBK

\section{Seliaan Dan Kos Insuran Tambahan}

Seliaan dan kos insurans tambahan adalah merupakan salah satu faktor yang menghalang majikan industri untuk terlibat dalam PBK. Ini adalah kerana majikan terpaksa memperuntukkan sejumlah wang untuk menyelia dan insuran untuk pelajar yang menjalani PBK di industri mereka. Umur pelajar yang mengikuti program PBK sedikit berbeza di Malaysia berbanding dengan negara luar. Di Malaysia, rata-rata umur pelajar program PBK adalah pada awal dua puluhan. Menurut Alaska Work Based Learning Guide (2003), undang-undang keselamatan yang berkaitan dengan PBK terbahagi kepada tiga iaitu aspek keselamatan umum, gaji dan insuran serta liabiliti. Isu-isu insurans adalah mendapat perhatian daripada kedua-dua belah pihak iaitu institusi dan industri. Terdapat empat isu yang menjadi kebimbangan mereka terhadap insuran iaitu sekiranya terdapat kecederaan yang berlaku kepada pelajar semasa di tempat kerja; kecederaan yang berlaku kepada pelajar semasa dalam transit ke atau dari tempat kerja, kecederaan kepada pelanggan atau pekerja tempat kerja, dan kerosakan kepada barangan syarikat. Oleh yang demikian, ini menjadikan majikan industri terasa terbeban dan tidak berminat untuk terlibat dalam PBK.

Insurans pampasan pekerja juga merupakan insuran tambahan yang perlu diambil oleh majikan industri terhadap pelajar PBK. Ia meliputi perbelanjaan perubatan dan kehilangan pendapatan untuk pekerja cedera di tempat kerja. Pelajar dalam program PBK mesti diinsuranskan di institusi dan juga di industri. Pampasan pekerja adalah diberikan dan dibayar oleh majikan; tiada potongan ditahan daripada gaji pekerja untuk perlindungan ini dan ini amat membebankan majikan daripada terlibat dengan PBK (Standards and Guidelines for Work-Based Learning Programs in Georgia, 2013). Hasil kajian OTA dalam Herdman (1995) pula mendapati bahawa menunjukkan bahawa halangan seliaan dan kos insuran adalah tersangat penting kepada sesetengah majikan iaitu sebanyak 6\% sahaja manakala kebanyakan majikan pula melihat halangan tersebut sebagai kurang penting adalah sebanyak $9 \%$. Lebih daripada $75 \%$ daripada majikan yang dikaji selidik oleh OTA berkata undang-undang buruh kanak-kanak, peraturan-peraturan keselamatan, dan kos insurans tidak mempunyai kesan ke atas keputusan mereka untuk mengambil bahagian dalam program PBK.

\section{Kurangnya Sokongan Dan Persediaan}

Kekurangan sokongan dan persedian dari pelbagai pihak iaitu majikan industri, institusi pendidikan dan juga pelajar merupakan salah satu faktor yang menyumbang kepada halangan majikan industri untuk terlibat dalam program PBK. Martin (2003) meyatakan bahawa pelajar telah mengenal pasti beberapa halangan kepada pembelajaran PBK mereka iaitu tekanan kerja, kekurangan keyakinan atau masa, isu-isu yang berkaitan di tempat kerja, budaya dan jantina. Zinman (2007) pula telah mengenal pasti bahawa terdapat tiga aspek iaitu masa, ruang, dan keupayaan yang menjadi faktor kurangnya sokongan industri untuk menimbang penyertaan mereka dalam program PBK. Manakala McGinnis (2006) pula menyatakan bahawa perkembangan projek, kakitangan dan pengurusan menenyebabkan mereka tidak dapat komited dan melibatkan diri dalam PBK kerana kekurangan masa peribadi, kemahiran mengajar dan juga wang. Dugan-Waldschrnidt (2002) pula menambah bahawa tenaga pengajar di industri adalah kurang berpengalaman daripada pensyarah di institusi pendidikan.

Berdasarkan kepada kajian OTA ini, sebanyak 23\% daripada majikan mengatakan bahawa kurangnya sokongan sebagai penghalang industri untuk terlibat dengan PBK. Manakala lebih daripada 70\% majikan menyatakan bahawa kekurangan bantuan teknikal dan sokongan penyelesaian masalah dan model program yang tidak fleksibel serta lebih daripada $60 \%$ majikan menyatakan sistem sekolah birokrasi juga tidak menjadi suatu isu yang menjadi halangan kepada keterlibatan industri dalam PBK dalam aspek kurangnya sokongan dan persediaan (Herdman, 1995). Kekurangan sokongan kakitangan yang berdedikasi atau organisasi pihak ketiga juga telah menimbulkan halangan dalam program PBK di California (WestEd, 2007). Tahap tinggi penglibatan kakitangan dalam pembangunan, pemilihan dan pemantauan pengalaman PBK boleh menguatkan, menyambungkan dan interaksi majikan dengan cara yang signifikan, dan membentuk 
teras, program yang kukuh stabil. Di samping itu, kualiti program PBK dapat diperkukuhkan melalui pembelajaran bersama, komunikasi dan perkongsian tanggungjawab di kalangan kakitangan syarikat.

\subsection{KESIMPULAN}

Kesimpulannya kaedah PBK sememangnya memerlukan perhubungan dua hala yang erat daripada kedua belah pihak iaitu pihak institusi pendidikan dan juga industri. Hubungan yang erat akan menjamin perlaksanaan kaedah PBK dengan lancar. Oleh yang demikian penyelidik telah membincangkan pelbagai model PBK yang mana menekankan kepada perhubungan dua hala antara institusi pendidikan dan juga pihak industri. Penyelidik juga telah menerangkan tentang faktor yang mempengaruhi pihak majikan untuk terlibat dalam PBK dalam tiga aspek iaitu motivasi philanthropy, kepentingan individu dan kolektif. Penyelidik juga membincangkan tentang potensi faedah yang akan diperolehi daripada hubungan kerjasama Politeknik dan industri serta faktor halangan yang terdapat semasa mewujudkan hubungan kerjasama antara Politeknik dan industri bagi menjayakan PBK. Penyelidik berharap agar konsep penglibatan yang telah disenaraikan dapat membantu pihak industri dan institusi untuk terus bekerjasama untuk menjayakan kaedah PBK.

\section{Rujukan}

A Guide for Employers for Work-Based Training. (2011). Northern Racing College The Stables Rossington Hall Great North Road Doncaster.

Alaska Work Based Learning Guide. (2003). Department of Education \& Early Development, Career \& Technical Education.

Arizona work-based learning resource guide. (2003). Arizona Department of Education Career and Technical Education Division. West Jefferson

Axmann, M. (2004). Facilitating Labour Market Entry For Youth Through Enterprise-Based Schemes In Vocational Education And Training And Skills Development, SEED Working Paper, No 48, Geneva: International Labour Organisation.

Bailey, T. \& Hughes, K. (1999). Employer Involvement in Work Based Learning Programs. Columbia University : Tesis.

Bailey, T. R. (1995) "Incentives for Employer Participation in School-to-Work Programs." in Learning To Work: Employer Involvement In School-To-Work Transition Programs. Washington, DC: Brookings Institution, 14-25

Bailey, T. R., Hughes, K., \& Barr, T. (2000). Achieving Scale And Quality In School-To-Work Internships: Findings From Two Employer Surveys. Educational Evaluation and Policy Analysis, 22, 41-64.

Bailey, T.R., Hughes, K.L. \&Thornton Moore, D. (2004). Working knowledge: Work-Based Learning And Education Reform. New York: Routledge Falmer.

Bassi, L. J., \& Ludwig, J. (2000). School-to-Work Programs In The United States: A Multi-Firm Case Study Of Training, Benefits, And Costs. Industrial and Labor Relations Review, 53, 219-239.

Becker, K. (2007). Digital Game-Based Learning Once Removed: Teaching Teachers. British Journal of Educational Technology, 38(3):478-488.

Boswell, W. R., Boudreau. J. W., \& Tichy, J. (2005). The Relationship Between Employee Job Change And Job Satisfaction: The Honeymoon-Hangover Effect. Journal of Applied Psychology, 90(5), 882-892.

Campbell, J. (1995). Understanding John Dewey. Nature And Co-Operative Intelligence. Chicago: Open Court

Canning, R. (1999). The Rhetoric and Reality of Professional Competence-Based Vocational Education in Scotland, University of Stirling.

CBI.(1998). 'Qualified to Compete: Creating A World-Class Qualifications Network', CBI Human Resources Brief, January

Collin, A. (2004). Goals Based Scenarios And The Problem Of Situated Learning. A Commentary On Anderson Consulting's Design Of The Goalbased Scenarios Education technology. November-December.30-32.

Council of Ontario University (1998). Sectoral Skill Needs. Ontario, Canada, 1-41.

Deitmer, L. (2011). Building up the Innovative Capabilities Of Workers. In P. Curtin, J. Stanwick and F. Beddie (ed.). Fostering Enterprise: The Innovation and Skills Nexus - Research Readings. Adelaide, Australia, National Centre for Vocational Education Research (NCVER), 38-51.

Dionisius, et al. (2008) Cost and Benefit of Apprenticeship Training: A Comparison of Germany and Switzerland. IZA Discussion Paper No. 3465.

Dore, R. \& Sako, M. (1998). How the Japanese Learn to Work, $2^{\text {nd }}$ edition. Routledge, London.

Dugan-Waldschmidt, E. (2002). Bilingual interns' barriers to becoming teachers: At what cost do we diversify the teaching force? Bilingual Research Journal, 26, 537-561.

Edmunds, J. (2007). A Personal View Of Work Based Learning: Policy And Practice From Both Ends Of The Telescope in Young, D. \& Garnett, J. (Eds.) Work-based Learning Futures Bolton: University Vocational Awards Council.

European Training Foundation. (2013). Work-based Learning: Benefits and Obstacles. A Literature Review for Policy Makers and Social Partners in ETF Partner Countries, ETF, Turin.

Fossum, J. A. (1995). Labour Relations. Irwin Publication.

Garavan et al. (2003). Making Training And Development Work: A Best Practice Guide. Cork: Daktree press

Glass, et al. (2002). Delivering Work Based Learning. Glasgow: Training And Employment Research Unit - University of Glasgow.

Herdman, R. (1995). Vocational Education Journal. 71(1), 13

Hershey et al. (1997). "Partners in Progress: Early Steps in Creating School-to-Work Systems, Executive Summary."Princeton, NJ: Mathematica Policy Research, Inc.

Hughes, K. L. (1996). Employer Motivations for Providing Work-Based Learning Placements to Students: Preliminary Results from Research in Progress. Lecture transcript. Toronto, Canada: APA Symposium.

Iowa Education Department.(2002). Work-based learning 2002. Dirujuk pada 4April 2014 di http://www.iaae.net/files/WorkplaceLearningGuide.pdf

Itoh, H. (1994). Japanese human resource management from the point of view of incentive theory. In M. Aoki and R. Dore (ed.). The Japanese Firm: The Sources of Competitive Strength. Oxford, Oxford University Press, 265-284.

Jarred, R. \& Jefsioutine, M. (2006). Reflection on Using Online Contact for Work-Based Learning and Teaching in Art and Design. Art, Design and Communication in Higher Education 5 (1).

Kazis, R., \& Goldberger, S. (1995). The role of employers: The Integration Of Work-Based Learning. In W. N. Grubb (Ed.), Education Through Occupations In American High Schools. Volume 2: The Challenges Of Implementing Curriculum Integration, 171-190. New York: Teachers College Press.

Koike, K. (1986). Company-Wide Approach Toward Participation And Motivation. Productivity And The Role of Top Management. Tokyo, Asian Productivity Organization.

Lemanski et al. (2011). An Introduction To Work-Based Learning: A Physical Sciences Practice Guide. The Higher Education Academy.

Lewis, L.V. (1997). Characteristics of successful school-to-work initiatives: What the research says. (Information Series No. 370). Columbus, OH:Center on Education and Training for Employment.

Linda C. S. (2013). Standards and Guidelines for Work-Based Learning Programs in Georgia. Georgia Department of Education.

Lynn, I., \& Wills, J. (1994). School Lessons, Work Lesson.Washington, DC: The Institute for Educational Leadership.

Lynne, B. H., (2003). Arizona Work-Based Learning Resource Guide. A Guide for Connecting Career and Technical Education to the Workplace. Arizona Department of Education

Martin, E. (1997). The Effectiveness of Different Models of Work-based University Education, Department of Employment, Education, Training and Youth Affairs, 96/19, Canberra: Evaluations and Investigations Program, Higher Education Division. 
McCulloch, K., McLaughlin, P. \& Allison, P. (2010). Sail Training As Education: More Than Mere Adventure, Oxford Review of Education, 36(6), 661-676.

McGinnis, L. F. (2006). Internships and Mentoring In High Performance Computing Environments. Proceedings of the 2006 ACWIEEE Conference on Super Computing, Tampa, FL, Article 42

McIntosh, S. (1999). A Cross Country Of The Determinants Of Vocational Training, London. London: London School Of Economics, Centre Of Economic Performance

Medrich, E.; Merola, L.; Ramer, C.; \& White, R. (2001). School-to-Work Progress Measures: A Report to the National School-to-Work Office. Berkeley, CA: MPR Associates; Washington, DC: Academy for Educational Development

Mills, V. \& Whittaker, S. (2001). Work Based Learning in Scottish Higher Education: Policy and Practicell Emerald Journal, 8(02), 64-69.

National Centre on Secondary Education and Training (NCSET) (2011). Work-Based Learning Programme. Dicapai dari scorecardforkskills.com

Office of Technology Assessment. (1995). Learning to Work: Making The Transition From School To Work. Washington, DC: U.S. Government Printing Office.

Okon, U. E. (2011). Work-Based Learning initiatives. Paper presented at Step-B/World Bank-assisted TVET Teachers Upskilling workshop held at the University of Nigeria, Nsukka from 23rdOctober - 4th November, 2011.

Oregon Work-Based Learning Manual, March.(1996). Lane Community College, Cooperative Education Department, 4000 East 30th Avenue, Eugene

Pauly, E.; Kopp, H, \& Haimson, J. (1994). Home-Grown Lessons:Innovative Programs Linking Work and High School. New York, NY: Manpower Demonstration ResearchCorporation,. (ED 369 939). .

Riggert, S. C., Ash, D., Boyle, M. A., Kinney, J., Howarth, D. A., \& RudyParkins, C. (2004). Metropolitan College: Building Community Value Through EducationBusiness Partnerships. Innovative Higher Education, 29(1), 7-19.

Schick, Ruth (2005) Employer Investment In Workplace Literacy Programmes. Workbase: Auckland.

Schrenko, L.C. (2010). Standards and Guidelines for Work-Based Learning Programmes in Georgia. State of Georgia Department of Education.

Seagraves et al. (1996). Learning in Smaller Companies (LISC) Final Report. University of Stirling: Educational Policy and Development.

Sims, D. \& Golden, S. (1998). A Study of Employers' Use of NVQs and SVQs Across Industrial Sectors, DfEE RR 51

Smits, W. (2008), The Private Benefits From Vocational Training: A New Framework, In Cedefop, Modernising Vocational Education And Training - Fourth Report On Vocational Training Research In Europe: Background Report Vol. 1, Luxembourg: Office for Official Publications of the European Communities.

Stephanie et al. (2013). America's Edge

Stone, J. R., III, \& Aliaga, O. A. (2003). Career and technical education, career pathways, and work-based learning: Changes in participation 1997-1999. St. Paul, MN: National Research Center for Career and Technical Education, University of Minnesota.

Stones, E. (1994). Assessment of a complex skill: Improving teacher education. Asssessment in Education, 1(2), 235-251.

Tajul Ariffin \& Ani Asmah. (2009). Innovative practices in TVET toward education for sustainable development: Work-based learning diploma programmes at community college in Malaysia. International experts meeting on reorienting TVET policy towards education for sustainable development, Berlin, Germany.

Taylor, S. (2001). Getting employers involved Improving work-based learning through employer links. Learning and Skills Development Agency.

Toner, P. (2011). Tradespeople and technicians in innovation. In P. Curtin, J. Stanwick and F. Beddie (ed.). Fostering Enterprise: The Innovation and Skills Nexus Research Readings. Adelaide, NCVER, pp. 127-143.

Rephrase the reference to United States Congress (1994). The School to Work Opportunities Act. Washington, US, $103-239$.

Vermont Agency of Education Work-Based Learning Manual. (2013). Work-Based Learning Guide: A Resource for Developing and Implementing Quality Experiences for Students. ISL High School \& Adult Division.

WestEd. (2006, December). A Statewide Assessment of California's Career Technical Education System. Retrieved from http:// www.wested.org/cteplan.

Wilson, J. (1997). Creating \& Initiating A Cooperative Education Program. Boston, MA: World Association for Cooperative Education Winsconsin Department of Public Instruction

Wisconsin Work-based Learning Guide (2002). Wisconsin Department of Public Instruction. Madison.

Work-based Learning Handbook Student/Tutor/Employer Guide (2010). BA (Hons) Early Years Education (Work-based) School of Education \& Weston College.

Worrells, D. S. (2006). The Nature And Status Of Work-Based Learning Within Aviation Management Programs: A Programmatic Perspective. Dissertation Abstracts International.

Zinman, M. (2007, January 1). Managers gain 225 days of productivity by having an intern. Retrieved August 5,2015, from http://www.collegerecruiter.comiintemshis/2007/Ol/managers gain 225 days of urod. hu 